\title{
Osuwisko na stokach Magury Witowskiej (Podhale)
}

\author{
Paweł Marciniec $^{1}$, Wojciech Granoszewski ${ }^{1}$, Ziemowit Zimnal ${ }^{1}$
}

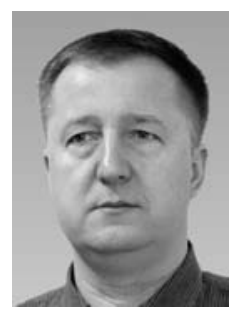

P. Marciniec

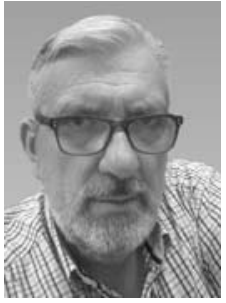

W. Granoszewski

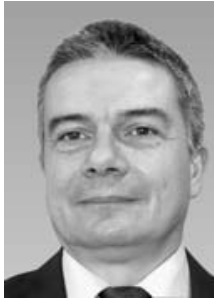

Z. Zimnal

Landslide on the slopes of Mt. Magura Witowska (Podhale). Prz. Geol., 67: 405-413; 10.7306/2019.35

A b s t $r$ a $c t$. The landslide on the northern slopes of Magura Witowska is an example of a consequent-structural type of landslide. It has been developed due to several favorable conditions like: monoclinal layer deposition where the dip angle and direction of collapsing layers are close to those of slope exposition. Moreover, shale packages are commonly present in the bedrock. In the lower part of the landslide an elongated basin filled with peat sediments is situated. The 8-m long profile was recovered with an Instorf sampler for ${ }^{14} \mathrm{C}$ dating and pollen analysis purposes. The results of radiocarbon dating and pollen analysis point to Subboreal and Subatlantic age of these sediments. Undisturbed biogenic sedimentation, lack of minerogenic intercalations together with the unbroken course of pollen succession suggest that the studied landslide has not undergone any significant active events since its formation.

Keywords: landslide, Holocene, Podhale, peatbog, pollen analysis

W obrębie osuwisk, wśród nabrzmień i wałów koluwialnych, niejednokrotnie występują zagłębienia bezodpływowe. W sprzyjających warunkach są one wypełnione osadami organicznymi, które można poddać badaniom palinologicznym oraz datowaniu bezwzględnemu. Daje to możliwość ustalenia lub oszacowania czasu powstania, a niekiedy etapów rozwoju danej formy osuwiskowej.

$\mathrm{W}$ ramach prac kartograficznych w celu sporządzenia Szczegółowej mapy geologicznej Tatr w skali 1:10 000 (SMGT) w 2005 i 2009 r. wykonano szczegółowe zdjęcie geologiczne zachodniej części Pogórza Gubałowskiego (Marciniec i in., 2015; Wasiluk i in., 2015) w rejonie Magury Witowskiej. Na północno-wschodnich stokach tego wzniesienia (ryc. 1) występuje największe powierzchniowo osuwisko (zespół osuwisk) na terenie Podhala, o charakterystycznej budowie wewnętrznej. W dolnej części osuwiska stwierdzono występowanie podłużnego zagłębienia bezodpływowego wypełnionego torfem, z którego sondą torfową pobrano materiał do badań radiowęglowych i analiz palinologicznych w celu ustalenia wieku powstania osuwiska oraz zmian paleoekologicznych w jego okolicy.

Osuwisko na stokach Magury Witowskiej było przedmiotem badań Kukulaka (1988), który analizował m.in. powiązania elementów morfostrukturalnych z rozwojem osuwisk zachodniego Podhala, oraz Długosza (2011), który uwzględnił analizowane osuwisko w badaniach podatności osuwiskowej tego rejonu. W obu pracach nie przedstawiono jednak pełnego zasięgu tego osuwiska. Nastąpiło to dopiero po opracowaniu SMGT (Marciniec i in., 2015; Wasiluk i in., 2015), Mapy osuwisk i terenów zagrożonych dla gminy Kościelisko (Wieczorek, Stoiński, 2010) oraz atlasu osuwisk województwa małopolskiego (Marciniec i in., 2012). Przeprowadzona później przez autorów analiza wysokorozdzielczego numerycznego modelu terenu, uzyskanego z lotniczego skaningu laserowego, a dostępnego w ramach Informatycznego Systemu Osłony Kraju (ISOK), pozwoliła na precyzyjniejsze wyznaczenie zasięgu osuwiska oraz uszczegółowienie i korektę rozmieszczenia niektórych elementów morfologii wewnątrzosuwiskowej w trudno dostępnych miejscach.

\section{CHARAKTERYSTYKA OSUWISKA}

Osuwisko jest usytuowane w Zachodnich Karpatach Wewnętrznych na Pogórzu Gubałowskim i rozwinęło się w źródłowej części Magurskiego Potoku (lewy dopływ Czarnego Dunajca) powstałego z połączenia potoków Bzdyków i Basiorów, na północno-wschodnim stoku Magury Witowskiej (1228,6 m n.p.m.), północnym stoku Witowskiego Przysłopu (1163,9 m n.p.m.) i północno-zachodnim stoku Hurchociego Wierchu (1055,6 m n.p.m.). Niewielki fragment osuwiska znajduje się na Słowacji. Osuwisko jest rozległe, jego powierzchnia wynosi 164,37 ha (długość $1400 \mathrm{~m}$, szerokość 1900 m) i rozciąga się od 865 do 1192 m n.p.m.

Jest to strukturalne osuwisko złożone (typu complex). Na północnych stokach Witowskiego Przysłopu jest rozwinięte jako klasyczne osuwisko konsekwentne, natomiast w całym obszarze leja źródłowego Magurskiego Potoku jest rozwinięte głównie jako subsekwentne (zachodnia część leja) i tylko w niewielkiej wschodniej części leja insekwentne. Niemal na całym obszarze osuwisko jest nieaktywne, jedynie w zachodniej części uaktywniają się niewielkie jego fragmenty (ryc. 1).

W podłożu całego osuwiska występują piaskowcowo-łupkowe utwory warstw chochołowskich dolnych fliszu podhalańskiego (Marciniec i in., 2015; Wasiluk i in., 2015). Flisz ten w południowo-zachodniej części niecki podhalańskiej jest nieskomplikowany pod względem litostratygraficznym, natomiast występują tu liczne złuskowania, nasunięcia i dyslokacje. Ze względu na dużą zmienność

\footnotetext{
${ }^{1}$ Państwowy Instytut Geologiczny - Państwowy Instytut Badawczy, Centrum Geozagrożeń, ul. Skrzatów 1, 31-560 Kraków; pawel.marciniec@pgi.gov.pl; wojciech.granoszewski@pgi.gov.pl; ziemowit.zimnal@pgi.gov.pl
} 


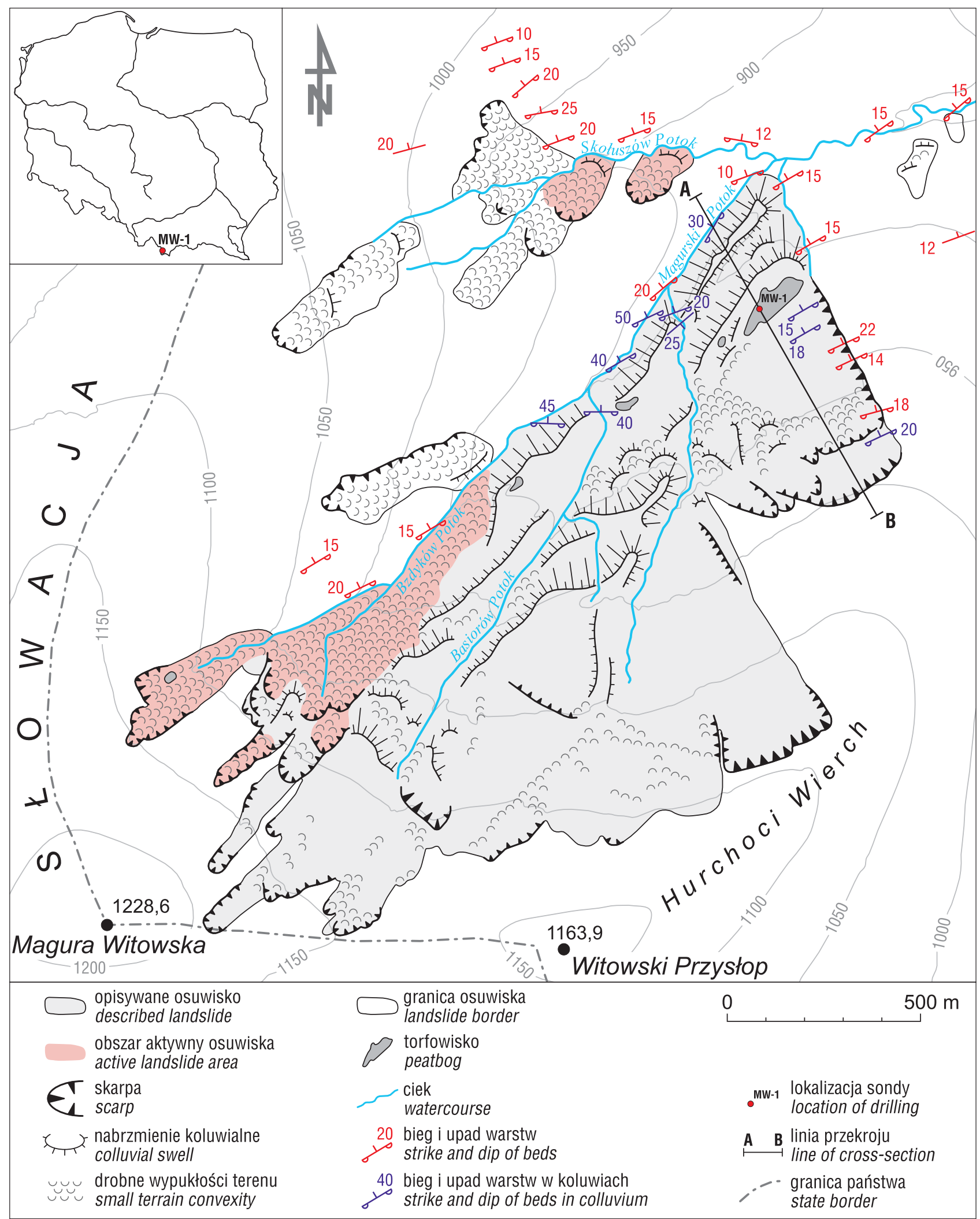

Ryc. 1. Szkic osuwiska na Magurze Witowskiej

Fig. 1. Sketch of the landslide on Mt. Magura Witowska

lateralną oraz monotonne i powtarzające się sekwencje, tak charakterystyczne dla fliszu podhalańskiego, są one trudne do dokładnego prześledzenia. Powierzchnie spękań i uskoków są najczęściej związane z kierunkiem NNW-SSE, znacznie rzadziej z kierunkiem W-E (Watycha, 1977; Kukulak, 1988). W rejonie skarpy głównej występują łupki ilaste, mułowce i piaskowce średnioławicowe, natomiast w środkowej i dolnej części osuwiska gruboławicowe piaskowce z wkładkami łupków (Marciniec i in., 2015; Wasiluk i in., 2015).

Osuwisko rozpoczyna się skarpą główną złożoną z wielu podrzędnych skarp o wysokości ok. 6-8 m w części 


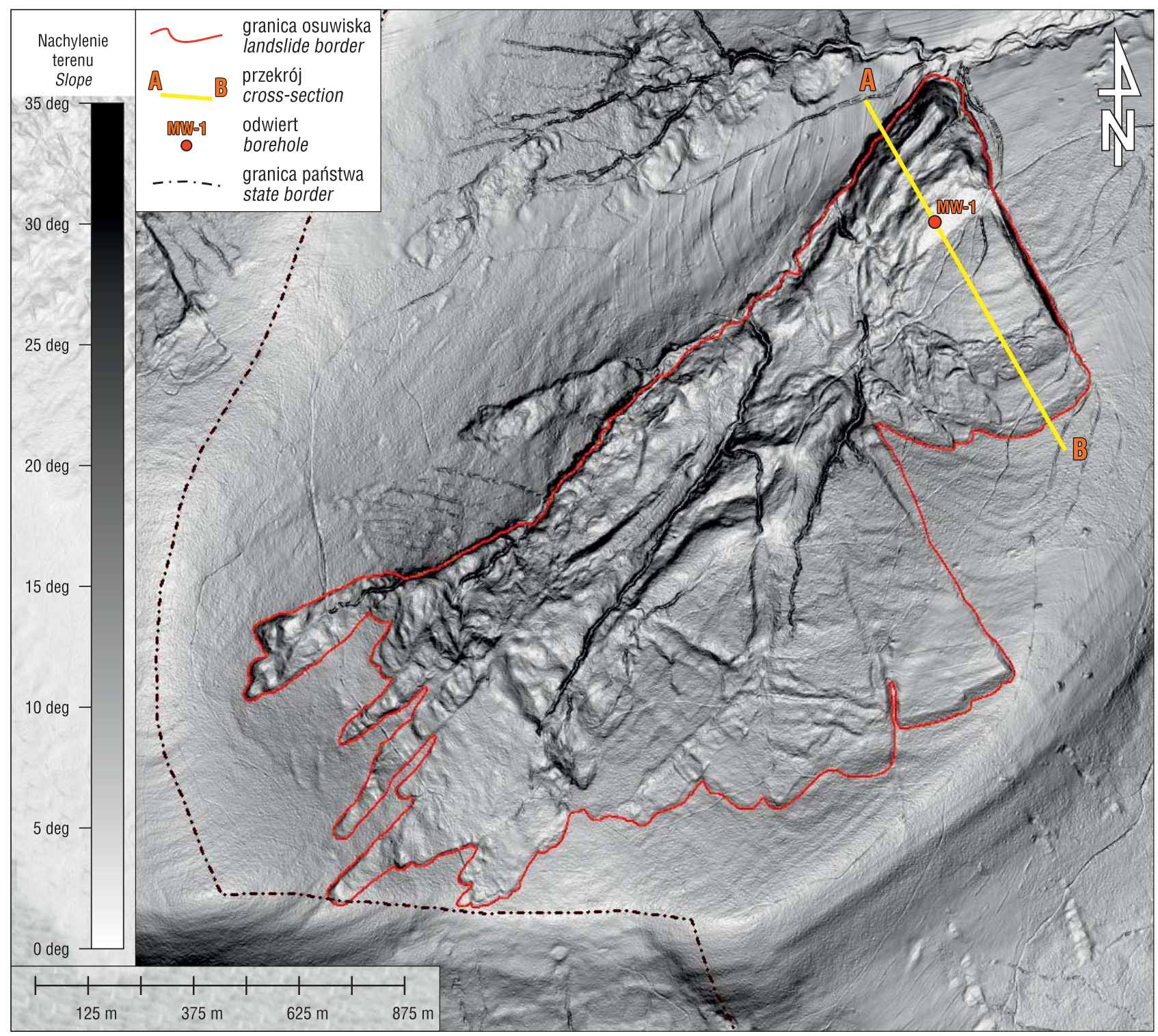

Ryc. 2. Model osuwiska na Magurze Witowskiej

Fig. 2. Model of the landslide on Mt. Magura Witowska

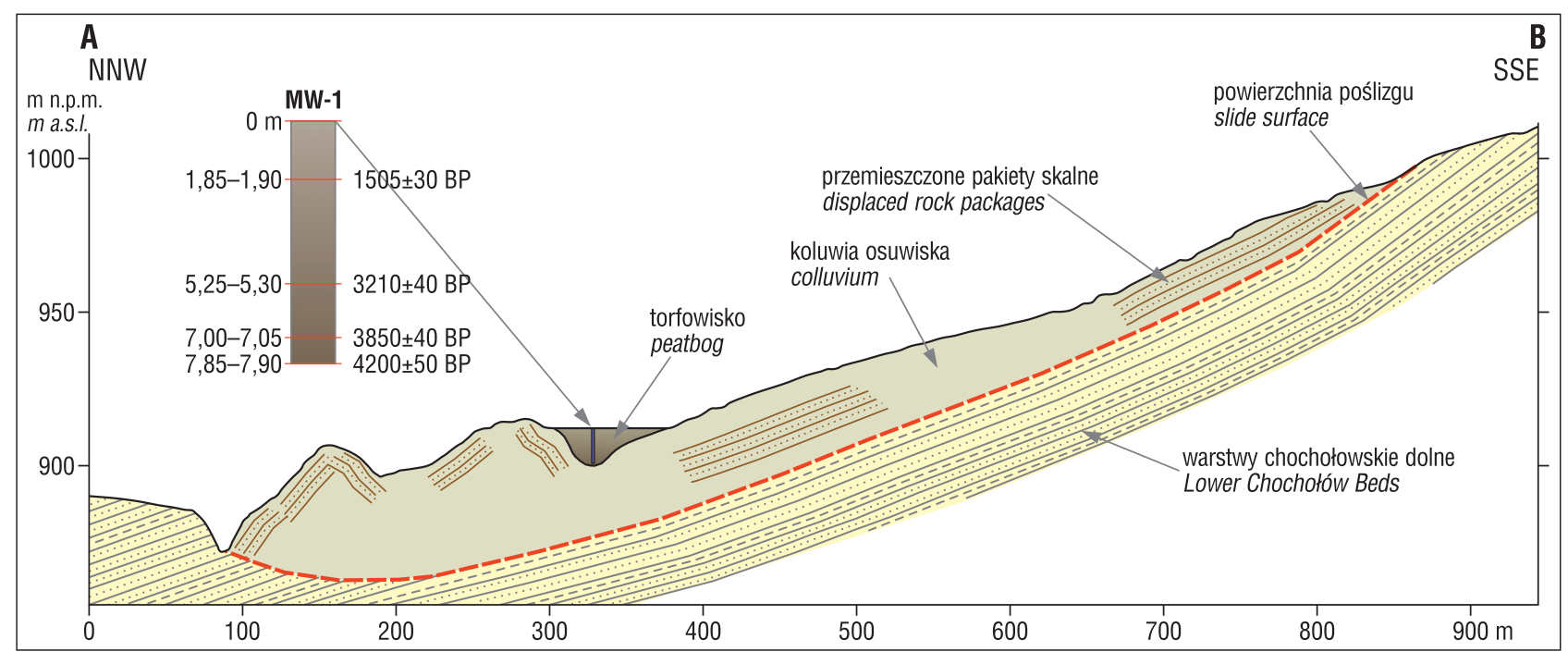

Ryc. 3. Przekrój przez osuwisko

Fig. 3. Landslides cross-section 
wschodniej, kilkudziesięciu cm do ok. 4 m w części środkowej, do ponad $16 \mathrm{~m}$ w części zachodniej (ryc. 1). Maksymalna miąższość koluwiów w osuwisku jest szacowana na ponad $20 \mathrm{~m}$. Schodzą one jęzorem do doliny Magurskiego Potoku.

Od strony wschodniej zaznaczają się wyraźne skarpy boczne o charakterystycznym prostolinijnym przebiegu i wysokości do kilku metrów (ryc. 2). Skarpy te mają założenia tektoniczne i nawiązują do systemu spękań i uskoków o przebiegu 170-330 (Watycha, 1977; Kukulak, 1988; Marciniec i in., 2015), podobnie jak w kilku innych tego typu osuwiskach na zachodnim Podhalu (Bober 1971, 1984; Kukulak, 1988; Michalik, 1962). Natomiast skarpy główne w południowo-wschodniej części osuwiska, słabo wyróżniające się w morfologii terenu, wyraźnie nawiązują do linii (intersekcji) wychodni utworów fliszowych, a nie jak pisze Kukulak (1988) do kierunków spękań ciosowych. Nachylenie tych skarp jest takie same jak kąt zapadania warstw (tj. 15-20) i niewiele większe od nachylenia stoku położonego powyżej, co powoduje, że są słabo widoczne (ryc. 3).

Ta część osuwiska reprezentuje typowe osuwisko konsekwentno-strukturalne ze zsuwem translacyjnym (przemieszczenie po powierzchni poślizgu zdominowanych przez powierzchnie strukturalne, zapadające w kierunku ruchu) po powierzchni uławicenia (Bober, 1971; Margielewski, 2006a, 2009). Sprzyja temu zarówno identyczny kierunek zapadania warstw i nachylenia stoku, jak i o kilka stopni większy kąt zapadania warstw (ryc. 3), w stosunku do kąta nachylenia stoku (kąt zapadania warstw: 15-18 kąt nachylenia stoku: 10-12). W dolnej części osuwiska występuje wyraźne spiętrzenie utworów koluwialnych (ryc. 4) i wychylenie zawartych w nich dużych pakietów piaskowców. Obserwować to można w jarze poprzecznie rozcinającym wał akumulacyjny czoła osuwiska, gdzie pakiety gruboławicowych piaskowców tworzą fałszywą antyklinę. Na skraju czoła pakiety piaskowców wychylone są w kierunku zsuwu i osiągają kąt zapadania od ok. 30 do nawet $50^{\circ}$ (ryc. 1,3 ). Natomiast na zapleczu wału

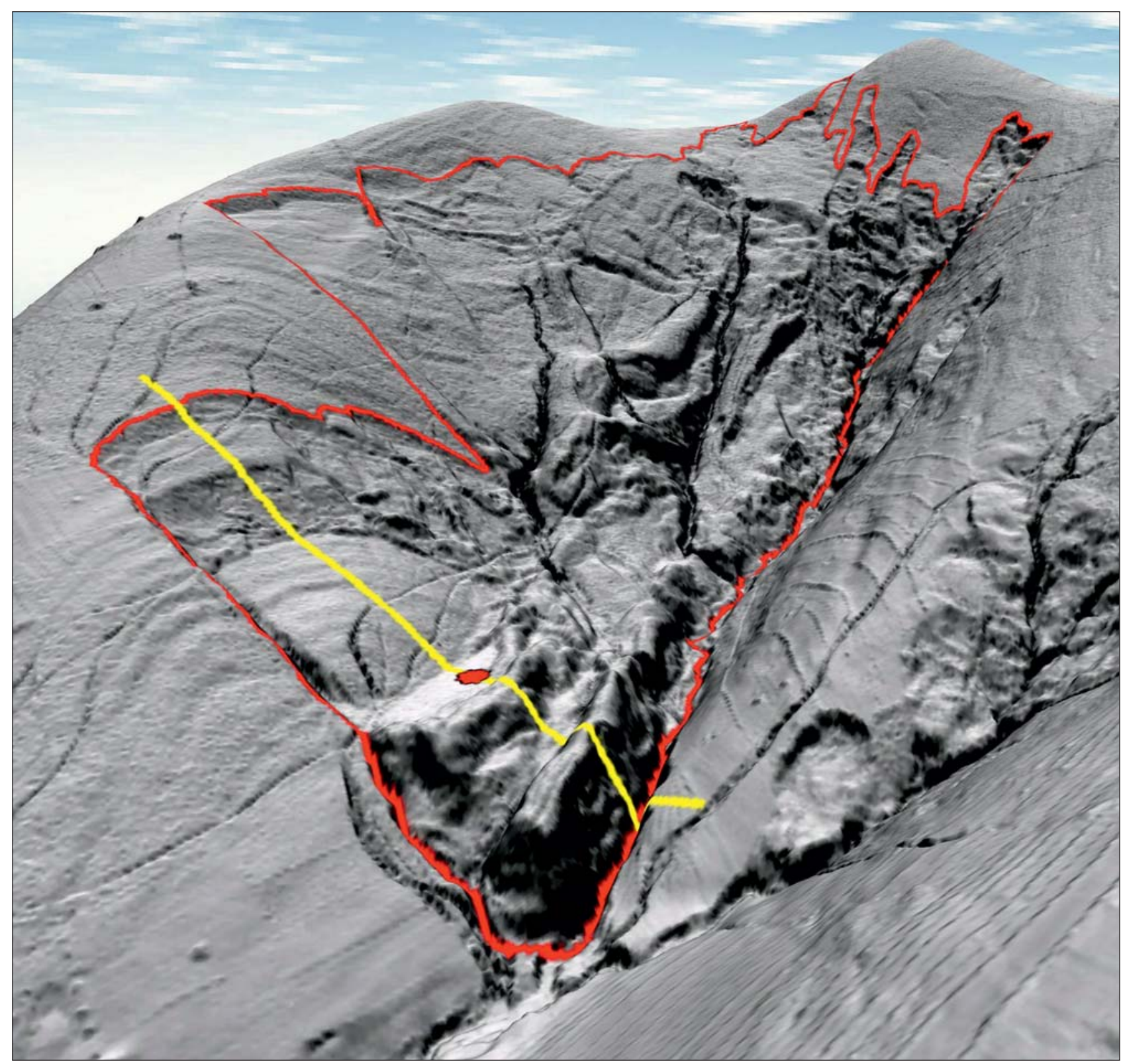

Ryc. 4. Zachodnia część osuwiska na Magurze Witowskiej, model 3D wygenerowany z NMT - widok od NE

Fig. 4. Western part of the landslide on Mt. Magura Witowska, 3D model generated from DEM - view from NE 
akumulacyjnego czoła pakiety piaskowców są wychylone w kierunku przeciwnym do nachylenia stoku, pod kątem ponad $20^{\circ}$.

Zupełnie odmienny charakter ma zachodnia część osuwiska, gdzie stwierdzono obecność niezbyt głębokich, równoległych do siebie zsuwów translacyjnych (ryc. 1, 2, 5). Obserwuje się tu subsekwentne osuwisko strukturalne o kierunku ruchu zbliżonym do biegu warstw, gdzie powierzchnia poślizgu jest założona na powierzchni uławicenia, natomiast skarpy boczne od południowego-wschodu nawiązują do wychodni warstw, a od północnego-zachodu do sieci spękań ciosowych (ryc. 1). Przebieg niewielkich pod względem długości skarp głównych jest determinowany przez siatkę spękań ciosowych i jest charakterystycznie „ząbkowany” (kształt ,piły”). Nachylenie tych skarp przeważnie przekracza $30^{\circ}$ i wyraźniej zaznaczają się one w morfologii terenu, w odróżnieniu od skarp w części wschodniej (ryc. 3). $\mathrm{W}$ tej części osuwiska również istotniejszym czynnikiem warunkującym jego powstanie jest budowa geologiczna, a w szczególności monoklinalny układ warstw o kącie i kierunku nachylenia zbliżonym do kąta i kierunku nachylenia stoku oraz stosunkowo duża ilość pakietów łupkowych o miąższości od kilkunastu centymetrów do ponad $1 \mathrm{~m}$.
W obrębie osuwiska obserwuje się skarpy wtórne i progi akumulacyjne o wysokości przekraczającej $20 \mathrm{~m}$ (ryc. 6). Występują również liczne otwarte spękania, rowy rozpadlinowe oraz zagłębienia odpływowe i bezodpływowe (ryc. 7, 8), często wypełnione glinami z rumoszem lub torfami. Największe z nich o powierzchni ponad 1 ha (ryc. 1, 4) jest zlokalizowane w dolnej, północno-wschodniej części jęzora osuwiska (Marciniec i in., 2015), a położone na wysokości $912 \mathrm{~m}$ n.p.m. Występujące pomiędzy pakietami osuniętego fliszu zagłębienie w formie głębokiego rowu, powstałego na zapleczu dużego wału akumulacyjnego, jest wypełnione torfami i mułkami torfiastymi (ryc. 8). Powstały wał i zagłębienie na jego zapleczu są bardzo charakterystyczne dla osuwisk konsekwentnych, rozwinię- tych na fliszu podhalańskim. Na obszarze torfowiska wykonano kilkanaście sondowań sondą ręczną, które pozwoliły na określenie głębokości i kształtu zbiornika. W najgłębszym miejscu miąższość osadów tego zbiornika wynosi ok. $9 \mathrm{~m}$.

\section{WIEK OSUWISKA}

W celu ustalenia wieku osuwiska oraz zmian roślinności i klimatu nawiercono za pomocą próbnika torfowego Instorf w najgłębszym miejscu torfowiska ciągły profil

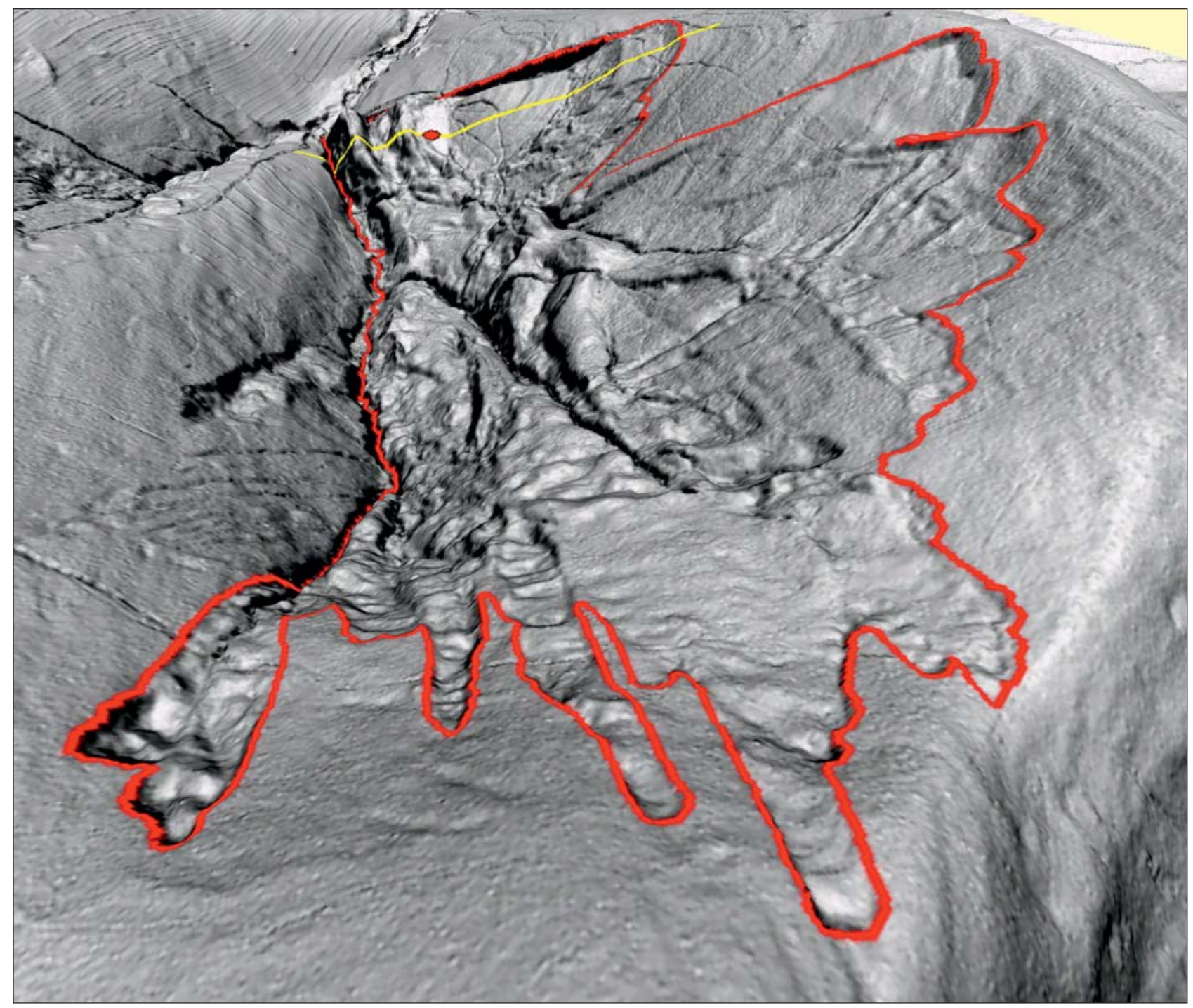

Ryc. 5. Wschodnia część osuwiska na Magurze Witowskiej, model 3D wygenerowany z NMT - widok od SW

Fig. 5. Eastern part of the landslide on Mt. Magura Witowska, 3D model generated from DEM - view from SW 


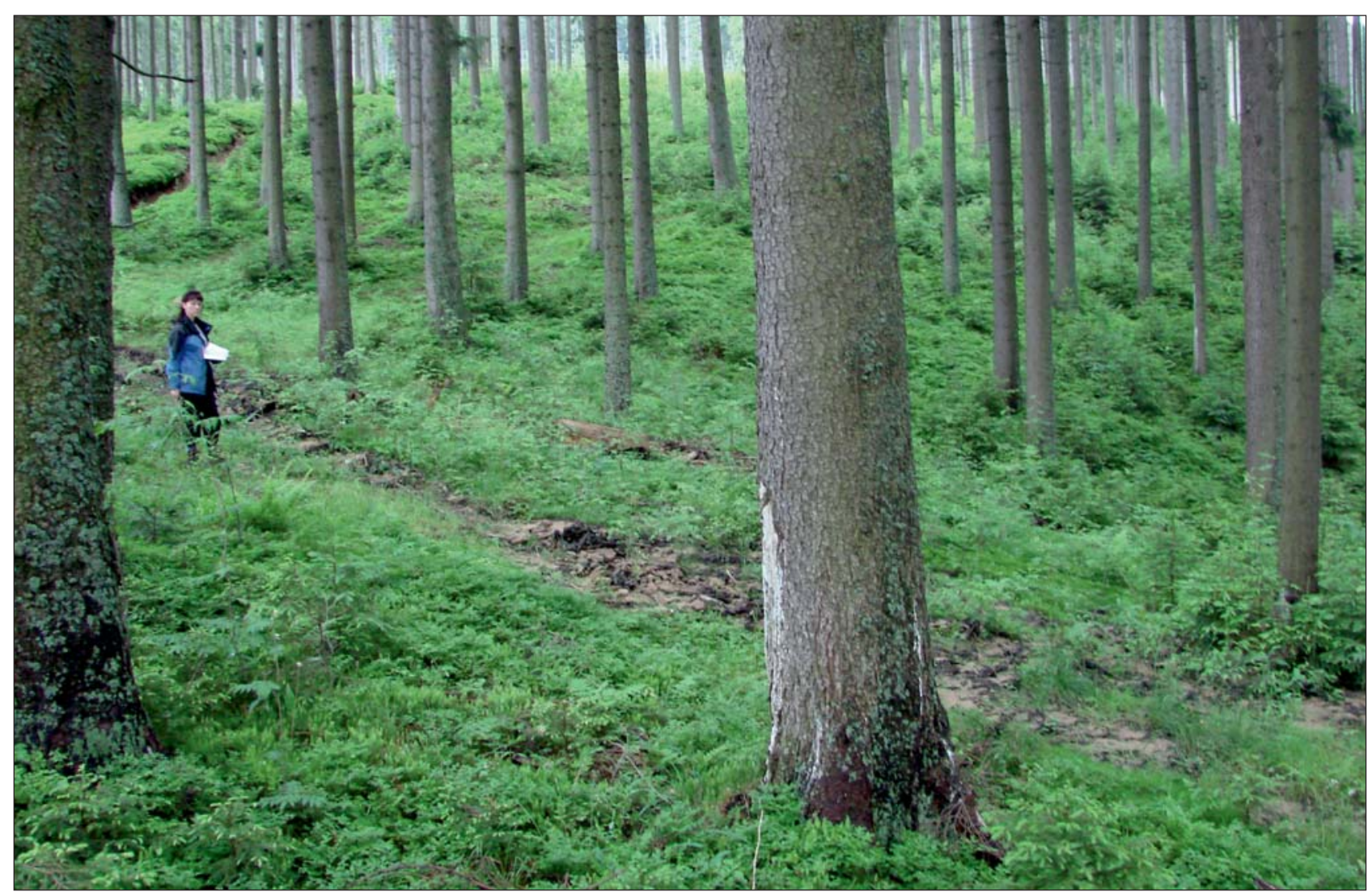

Ryc. 6. Potężne garby akumulacyjne w środkowej części jęzora

Fig. 6. Large colluvial swells in the middle of the toe

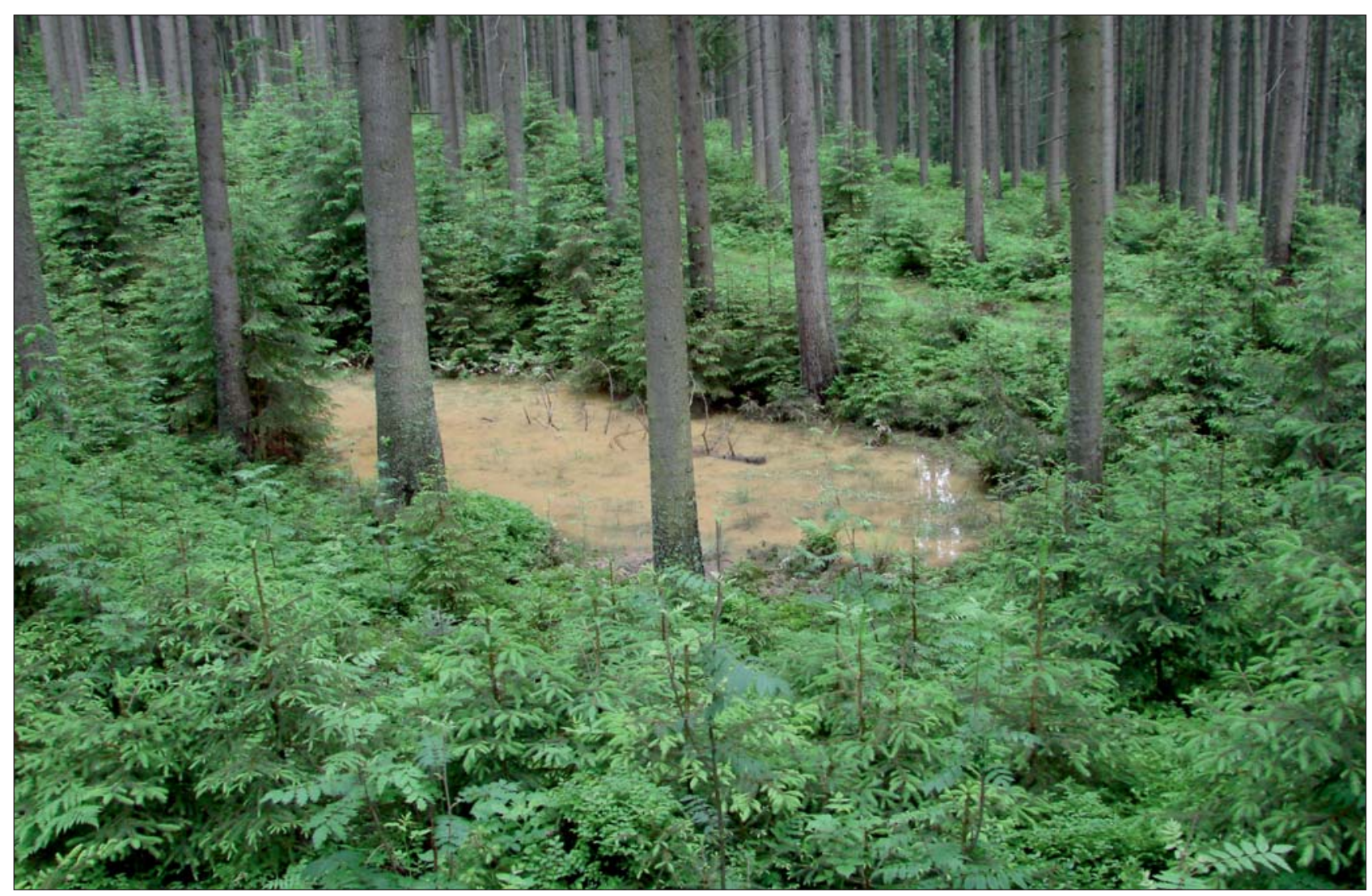

Ryc. 7. Zagłębienie bezodpływowe o średnicy ponad $6 \mathrm{~m}$ wypełnione wodą

Fig. 7. Water basin over $6 \mathrm{~m}$ in diameter 


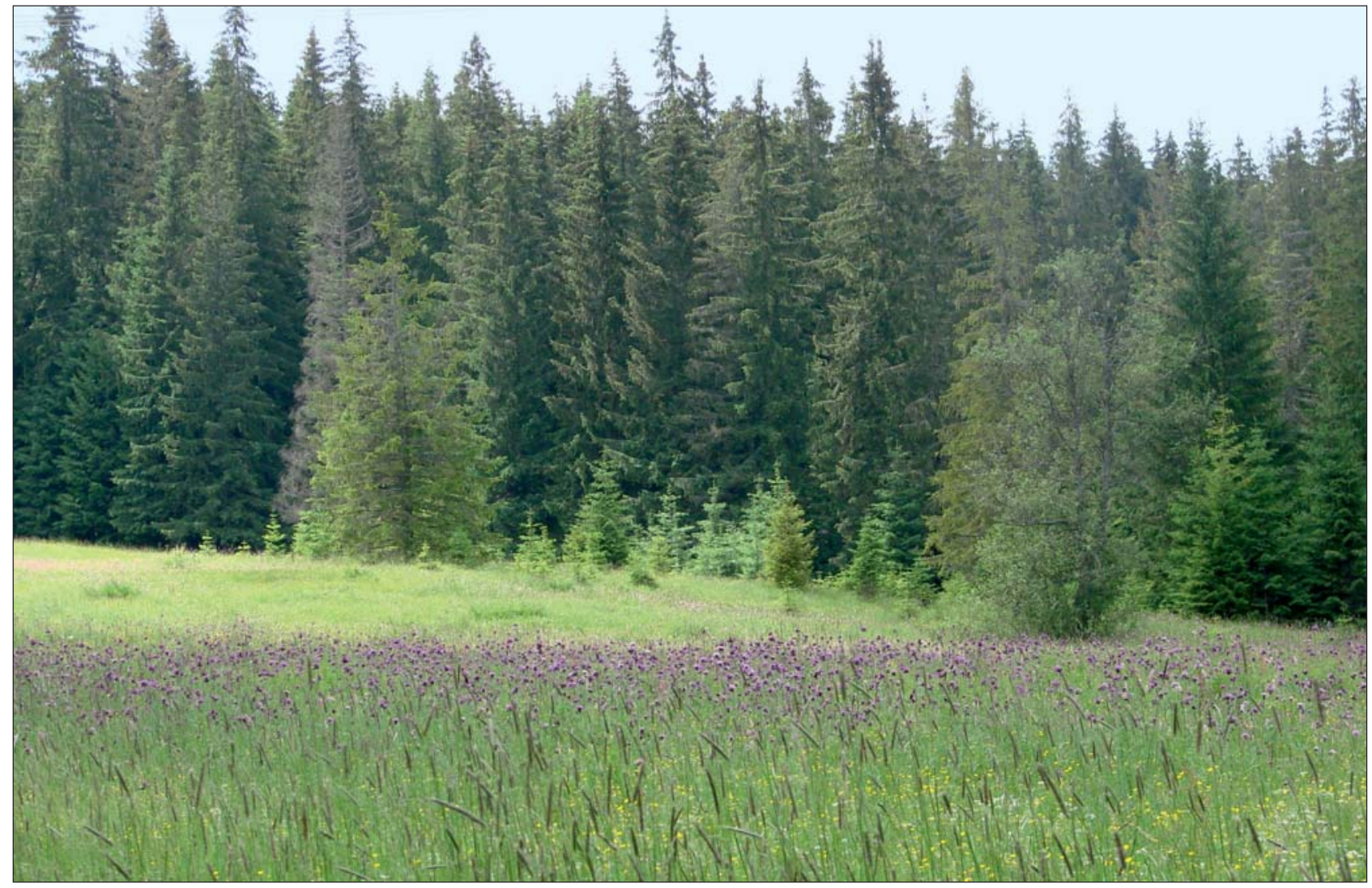

Ryc. 8. Torfowisko na zapleczu wału akumulacyjnego czoła osuwiska

Fig. 8. Peatbog in the back of the accumulation shaft of the landslide

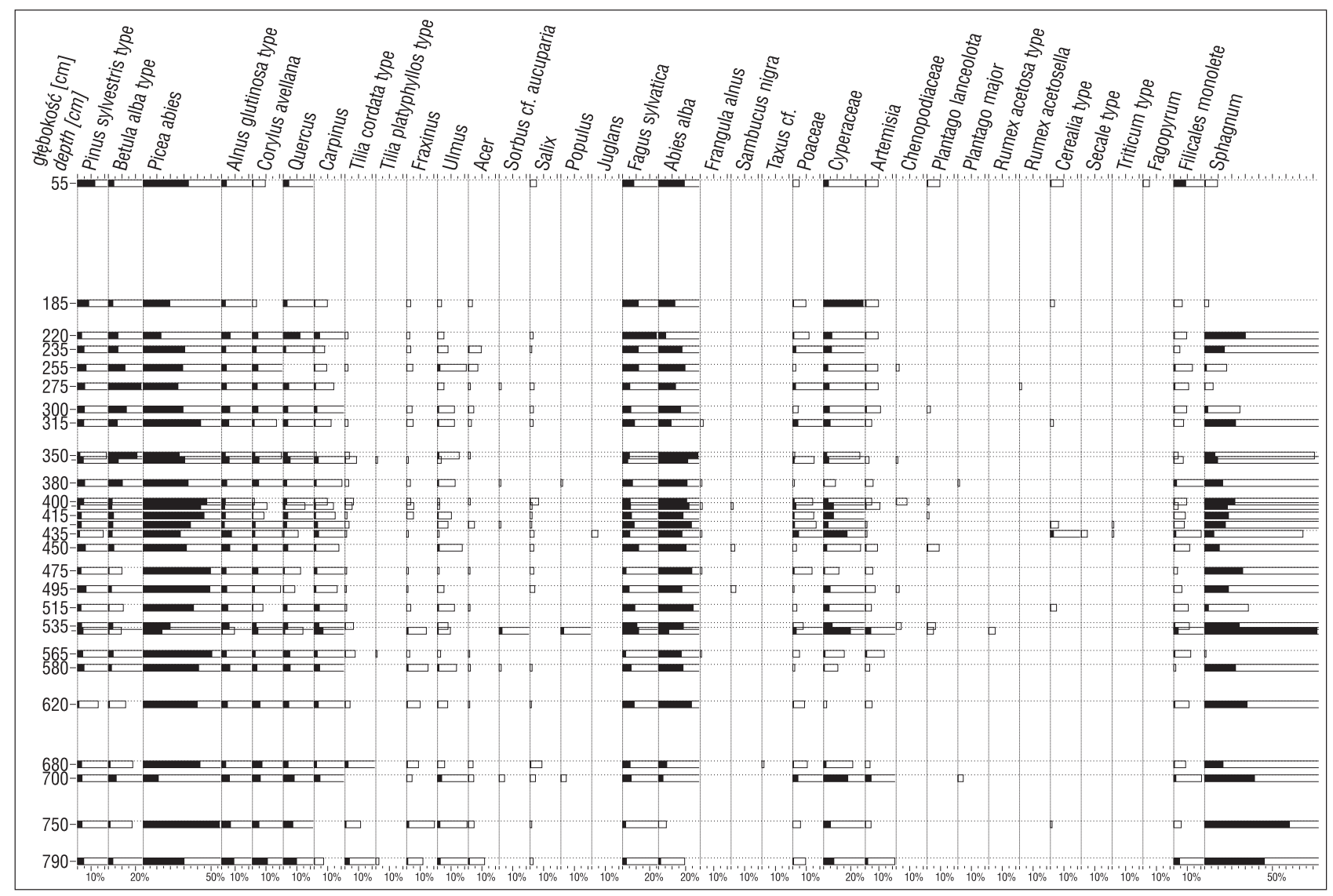

Ryc. 9. Uproszczony diagram pyłkowy z otworu MW-1, Magura Witowska

Fig. 9. Simplified percentage pollen diagram from borehole MW-1, landslide on Mt. Magura Witowska 
osadów organicznych o miąższości $8 \mathrm{~m}$ (ryc. 3, profil MW-1). Niestety ze względu na dużą ilość bloków piaskowcowych i pni drzew na dnie zagłębienia nie osiagnięto spagu osadów wypełniających zagłębienie bezodpływowe. Wykonano badania próbek osadu metodą analizy pyłkowej (ryc. 9) oraz cztery datowania radiowęglowe metodą AMS ${ }^{14} \mathrm{C}$ w Poznańskim Laboratorium Radiowęglowym (tab. 1).

\section{BADANIA PALINOLOGICZNE}

Maceracja próbek do badań palinologicznych obejmowała standardową procedurę opisaną przez Faegriego i Iversena (1989). Części mineralne odseparowano przy użyciu metody flotacji, wykorzystując $\mathrm{ZnCl}_{2}$ o ciężarze właściwym ok. 1,9 g/ $\mathrm{cm}^{3}$ (Nakagawa i in., 1998). Do narysowania diagramu pyłkowego użyto programu POLPAL (Walanus, Nalepka, 1999). Sumę podstawową, względem której obliczono udział poszczególnych taksonów pyłkowych w spektrach, stanowił pyłek roślin lądowych. Udział pyłku taksonów lokalnych, zarodników oraz glonów obliczono w stosunku do sumy podstawowej. Na profil składają się torfy torfowcowo-turzycowe o różnym stopniu rozłożenia (tab. 2).

Datowania radiowęglowe oraz przebieg sukcesji pyłkowej w profilu MW-1 wskazują na subborealny i subatlantycki wiek badanych osadów. Przejście od okresu atlantyckiego do subborealnego w Europie wyznacza spadek pyłku wiązu (Ulmus) (Latałowa, 2003). Najprawdopodobniej już schyłkowa faza tego zjawiska została zarejestrowana w osadach z torfowiska na Magurze Witowskiej. Wartości pyłku wiązu w trzech spagowych spektrach wynoszą od 3 do $5,5 \%$ i są wyraźnie wyższe od spektrów z próbek młodszych. W okresie subborealnym w rejonie Witowa dominowały zbiorowiska leśne ze świerkiem (Picea abies) w reglu górnym, a w niższych położeniach lasy grabowo-lipowe z dębem i leszczyną. Ciągłe, aczkolwiek o stosunkowo niskich wartościach, krzywe pyłku jodły (Abies alba) i buka (Fagus sylvatica) wskazują na formowanie się zbiorowisk regla dolnego czyli lasów bukowo-jodłowych. Od ok. 3850 lat BP i później miała miejsce silna ekspansja jodły na Podhalu. Wskazuje to na zwilgotnienie klimatu i rozwój dolnoreglowych lasów w typie buczyny karpackiej (Obidowicz, Nalepka, 2013). Osady torfowe podobnego wieku z Palenicy na Podhalu, powstałe również w wyniku ruchów osuwiskowych, zostały opisane przez Harmatę (1969). Nie posiadają one datowań radiowęglowych, ale bliźniacze podobieństwo obydwu sukcesji pyłkowych nie budzi wątpliwości i świadczy o ich podobnym wieku. Margielewski (2006b) na podstawie zbioru datowań radiowęglowych wskazuje na wyraźną koncentrację powstawania osuwisk w Karpatach ok. 5000 lat BP i łączy to zjawisko ze zwilgotnieniem klimatu, mającym miejsce na początku okresu subborealnego (Alexandrowicz, 1997; Starkel 1997; Margielewski, 1998). Najstarsza data $\mathrm{z}$ torfowiska na Magurze Witowskiej ma wartość $4200 \pm 50$ lat BP, a biorąc pod uwagę fakt, że nawiercony profil nie osiagnął spagu osadów z dużym prawdopodobieństwem można przyjąć, że również na Pogórzu Gubałowskim doszło do wzmożenia procesów stokowych w okresie subborealnym.

Sprawą otwartą jest bezpośrednia przyczyna powstania osuwiska. Budowa geologiczna w połączeniu ze zwilgotnieniem klimatu predysponowały badany obszar do rozwijania się ruchów masowych. Nie można jednak wykluczyć, że bezpośrednim impulsem do powstania osuwiska było trzęsienie ziemi. Taką przesłanką mogą być trzęsienia notowane w czasach historycznych na obszarze zachodniego Podhala (Pagaczewski, 1972; Hojny-Kołoś, 2008).

\section{PODSUMOWANIE}

Kompleks osuwiskowy na północnych stokach Magury Witowskiej, będący największym powierzchniowo na Podhalu, w świetle klasyfikacji osuwisk należy do typu konsekwentno-strukturalnych. Najistotniejszym biernym czynnikiem predysponującym do ruchów masowych na opisywanym obszarze jest budowa geologiczna, a w szczególności monoklinalny układ warstw o kącie i azymucie

Tab. 1. Wyniki datowania metodą AMS ${ }^{14} \mathrm{C}$ próbek z profilu MW-1 Table 1. AMS ${ }^{14} \mathrm{C}$ dating of the MW-1 profile

\begin{tabular}{|c|c|l|c|l|}
\hline $\begin{array}{c}\text { Glębokość }[\mathrm{m}] \\
\text { Depth }[\mathrm{m}]\end{array}$ & $\begin{array}{c}\text { Nr laboratoryjny } \\
\text { Laboratory No. }\end{array}$ & $\begin{array}{c}\text { Datowany material } \\
\text { Dated material }\end{array}$ & $\begin{array}{c}\text { Wiek }{ }^{14} \mathbf{C} \text { BP } \\
\text { Age }{ }^{14} \text { C BP }\end{array}$ & $\begin{array}{l}\text { Wiek kalibrowany BC/AD } \\
\text { Calibrated Age BC/AD }\end{array}$ \\
\hline $1,85-1,90$ & Poz-35089 & $\begin{array}{l}\text { torf sfagnowo-turzycowy } \\
\text { peat-sedge peat }\end{array}$ & $1505 \pm 30$ & $\begin{array}{l}\sigma 2 \\
530-640 \mathrm{AD}\end{array}$ \\
\hline $5,25-5,30$ & Poz-35090 & $\begin{array}{l}\text { torf turzycowy } \\
\text { sedge peat }\end{array}$ & $3210 \pm 40$ & $\begin{array}{l}\sigma \\
1540-1410 \mathrm{BC}\end{array}$ \\
\hline $7,00-7,05$ & Poz-35091 & $\begin{array}{l}\text { torf sfagnowo-turzycowy } \\
\text { peat-sedge peat }\end{array}$ & $3850 \pm 40$ & $\begin{array}{l}\sigma 2 \\
2460-2200 \mathrm{BC}\end{array}$ \\
\hline $7,85-7,90$ & Poz-35092 & $\begin{array}{l}\text { Menyanthes nasiona } \\
\text { Menyanthes seeds }\end{array}$ & $4200 \pm 50$ & $\begin{array}{l}\sigma 2 \\
2910-2620 \mathrm{BC}\end{array}$ \\
\hline
\end{tabular}

Tab. 2. Uproszczona litologia osadów torfowiska na Magurze Witowskiej Table 2. Simplified lithology of peat sediment from Mt. Magura Witowska

\begin{tabular}{|c|l|}
\hline $\begin{array}{c}\text { Glębokość }[\mathbf{m}] \\
\text { Depth }[\mathbf{m}]\end{array}$ & \multicolumn{1}{c|}{$\begin{array}{c}\text { Osad } \\
\text { Sediment }\end{array}$} \\
\hline $0,00-3,00$ & $\begin{array}{l}\text { torf turzycowy słabo rozłożony, ciemnobrunatny, z niewielkimi kawałkami drewna } \\
\text { the sedge peat is poorly distributed, dark brown, with small pieces of wood }\end{array}$ \\
\hline $3,00-8,00$ & $\begin{array}{l}\text { torf turzycowy średnio rozłożony, ciemnobrunatny, na gł. 6,30-6,50 natrafiono na duży fragment drewna } \\
\text { (? pień/korzeń), pobrano osad obok głównego profilu } \\
\text { the sedge peat medium spread, dark brown, at a depth of 6.30-6.50 a large piece of wood (? stem/root), } \\
\text { sediment sample was collected next to the main profile }\end{array}$ \\
\hline
\end{tabular}


nachylenia zbliżonym do kąta i azymutu nachylenia stoku oraz stosunkowo duża ilość pakietów łupkowych o miąższości od kilkunastu cm do ponad $1 \mathrm{~m}$. Do głównych kierunków tektonicznych i spękań ciosowych nawiązująjedynie boczne skarpy osuwiska oraz niewielkie fragmenty skarpy głównej w zachodniej części. Natomiast przebieg skarpy głównej jest zgodny $z$ intersekcją warstw. Niezaburzona sedymentacja organiczna torfów, brak przewarstwień mineralnych oraz przebieg krzywych pyłkowych wskazywałaby, że od czasu powstania osuwiska $\mathrm{w}$ okresie subborealnym nie miały miejsca znaczące uaktywnienia się (odmłodzenia) wschodniej części osuwiska.

Autorzy składają podziękowania Recenzentom za cenne uwagi, które pozwoliły udoskonalić treść i formę artykułu.

\section{LITERATURA}

ALEXANDROWICZ S.W. 1997 - Holocene dated landslides in the Polish Carpathians. [W:] Frenzel B. (red.), Rapid mass movement as a source of climatic evidence for the Holocene. Palaeoclim. Res. 19: 75-83.

BOBER L. 1971 - Structural landslides of the Podhale Region (Polish Inner Carpathians). Acta Geol. Acad. Sc. Hung., 15: 389-403.

BOBER L. 1984 - Rejony osuwiskowe w polskich Karpatach fliszowych i ich związek z budowa geologiczną regionu. Biul. Inst. Geol., 340: $115-162$.

DŁUGOSZ M. 2011 - Podatność stoków na osuwanie w polskich Karpatach fliszowych. Pr. Geogr. IGiPZ PAN, 230: 1-112.

FAEGRI K., IVERSEN J. 1989 - Textbook of Pollen Analysis. $4^{\text {th }}$ Edition,Wiley \& Sons, New York, Chichester: 1-328

HARMATA K. 1969 - Materiały do postglacjalnej historii roślinności Karpat Zachodnich. Torfowisko na Palenicy (Pogórze Gubałowskie). Fol. Quatern., 33: 1-14.

HOJNY-KOŁOŚ M. 2008 - Trzęsienia ziemi w Polsce. Geografia w szkole, 6: 33-41.

KUKULAK J. 1988 - Powiazania morfostrukturalne w rozwoju osuwisk zachodniego Podhala. Fol. Geogr., Ser. Geogr.-Phys., 20: 33-49.

LATAŁOWA M. 2003 - Holocen. [W:] Dybova-Jachowicz S., Sadowska A (red.) Palinologia. Inst. Bot. PAN, Kraków: 273-299.

MARCINIEC P., ZIMNAL Z., GRANOSZEWSKI W. 2012 - Witów osuwisko na Magurze Witowskiej. [W:] Chowaniec J., Wójcik A. (red.), Osuwiska w województwie małopolskim, Atlas - przewodnik. Wyd.
Departament Środowiska, Rolnictwa i Geodezji Urzędu Marszałkowskiego Województwa Małopolskiego, Kraków: 53-55.

MARCINIEC P., ZIMNAL Z., NESCIERUK P.,WASILUK R. 2015 Szczegółowa Mapa Geologiczna Tatr 1:10 000, ark. Witów, Państw. Inst. Geol., Warszawa.

MARGIELEWSKI W. 1998 - Landslide phases in the Polish Outer Carpathians and their relation to the climatic changes in the Late Glacial and the Holocene. Quatern. Stud. Pol., 15: 37-53.

MARGIELEWSKI W. 2006a - Structural control and types of movements of rock mass in anisotropic rocks: case studies in the Polish Flysch Carpathians. Geomorph., 77 (1-2): 47-68.

MARGIELEWSKI W. 2006b - Records of the late Glacial-Holocene Palaeoenvironmental changes in landslide form and deposits of the Beskid Makowski and Beskid Wyspowy Mts. area (Polish Outer Carpathians). Fol. Quatern., 76: 1-149.

MARGIELEWSKI W. 2009 - Problematyka osuwisk strukturalnych w Karpatach fliszowych w świetle zunifikowanych kryteriów klasyfikacji ruchów masowych - przegląd krytyczny. Prz. Geol., 57: 905-917.

MICHALIK A. 1962 - Osuwisko w Cichem na Podhalu. Rocz. Nauk.-Dydakt. WSP Kraków, z. 10.

NAKAGAWA T., BRUGIAPAGLIA E., DIGERFELD G., REILLE M., BEAULIEU J.-L. DE, YASUDA Y. 1998 - Dense-media separation as a more efficient pollen extraction method for use with organic sediment/deposit samples: comparison with the conventional method. Boreas, 27: $15-24$

OBIDOWICZ A., NALEPKA D. 2013 - Abies alba Mill. - Fir. [W:] Obidowicz A., Madeyska E., Turner C. (red.), Postglacial history of vegetation in the Polish part of the Western Carpathians based on isopollen maps. W. Szafer Institute of Botany, Polish Academy of Sciences, Kraków: 31-33. PAGACZEWSKI J. 1972 - Catalogue of earthquakes in Poland in 1000-1970 years. Publs. Inst. Geoph. Pol. Acad. Sci., 51: 3-36.

STARKEL L. 1997 - Mass movement during the Holocene: Carpathian example and the European perspective. [W:] Frenzel B. (red.), Rapid mass movement as a source of climatic evidence for the Holocene. Palaeoclim. Res., 19: 385-400.

WALANUS A., NALEPKA D. 1999 - POLPAL. Program for counting pollen grains, diagrams plotting and numerical analysis. Acta Palaeobot., 2: 659-661

WASILUK R., MARCINIEC P., ZIMNAL Z. 2015 - Szczegółowa Mapa Geologiczna Tatr 1: 10 000, ark. Magura Witowska. Państw. Inst. Geol., Warszawa.

WATYCHA L. 1977 - Objaśnienia do Szczegółowej Mapy Geologicznej Polski 1 : 50 000, ark. Czarny Dunajec. Wyd. Geol., Warszawa.

WIECZOREK D., STOIŃSKI A. 2010 - Mapa osuwisk i terenów zagrożonych dla gminy Kościelisko w skali 1: 10 000. Nar. Arch. Geol. PIG-PIB, Warszawa.

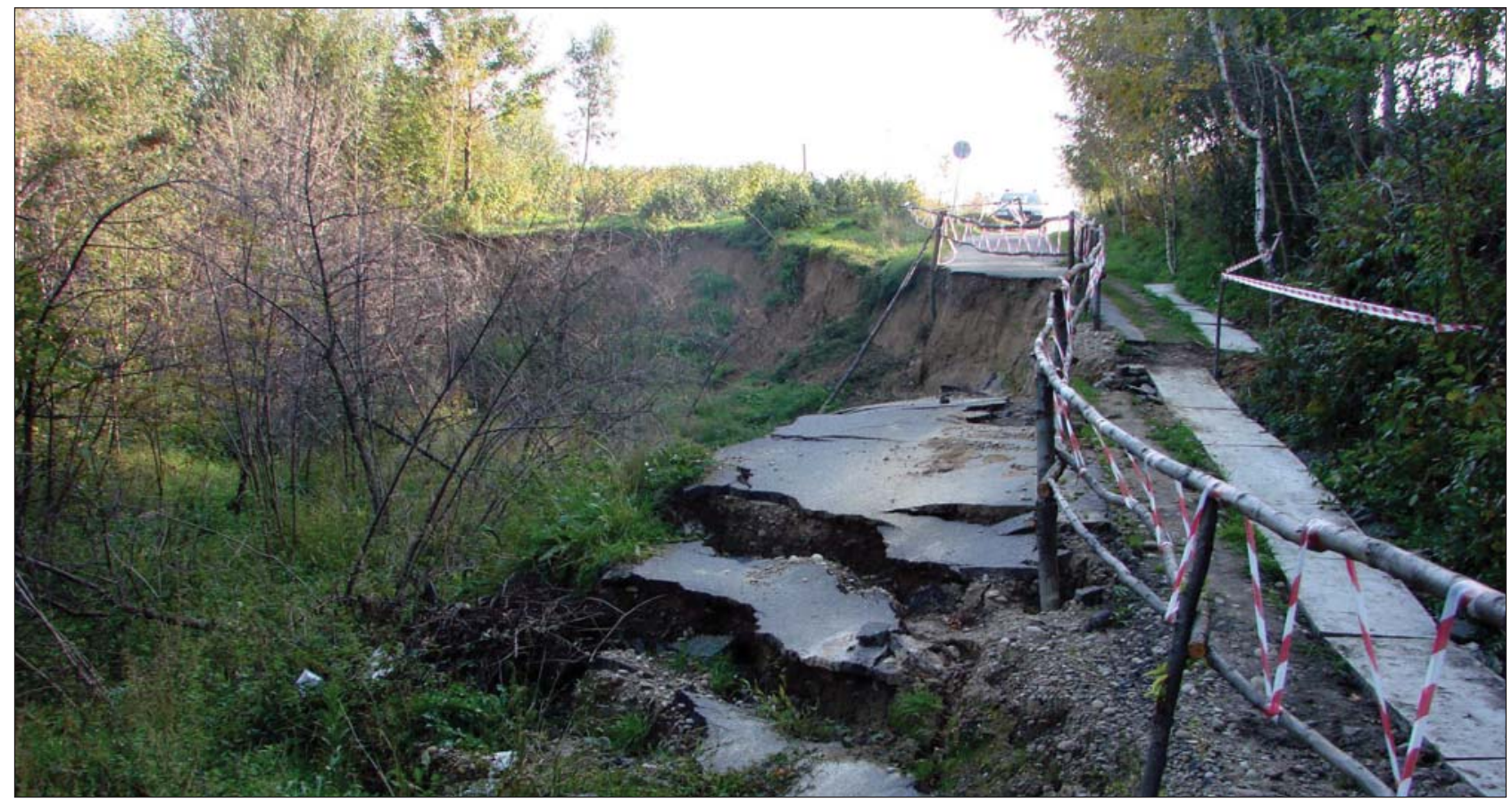

Aktywne osuwisko niszczące drogę gminną w miejscowości Grabno (gmina Wojnicz, powiat tarnowski). Fot. P. Marciniec An active landslide damaging the municipal road in Grabno (Wojnicz commune, tarnowski county). Photo by P. Marciniec 